\title{
Identification and Pathogenicity of Bacteria Associated with Etiolation and Decline of Creeping Bentgrass Golf Course Putting Greens
}

\author{
Joseph A. Roberts, ${ }^{\dagger}$ Bangya Ma, Lane P. Tredway, David F. Ritchie, and James P. Kerns
}

First, third, fourth, and fifth authors: Department of Entomology and Plant Pathology, North Carolina State University, Campus Box 7616,2510 Thomas Hall, Raleigh 27695; and second author: SePRO Corporation, 16013 Watson Seed Farm Rd., Whitakers, NC 27891.

Current address of first author: Department of Plant Science and Landscape Architecture, University of Maryland, 2110 Plant Sciences Building, College Park 20742.

Accepted for publication 13 August 2017.

\begin{abstract}
Bacterial etiolation and decline has developed into a widespread issue with creeping bentgrass (CBG) (Agrostis stolonifera) putting green turf. The condition is characterized by an abnormal elongation of turfgrass stems and leaves that in rare cases progresses into a rapid and widespread necrosis and decline. Recent reports have cited bacteria, Acidovorax avenae and Xanthomonas translucens, as causal agents; however, few cases exist where either bacterium were isolated in conjunction with turf exhibiting bacterial disease symptoms. From 2010 to 2014, turfgrass from 62 locations submitted to the NC State Turf Diagnostic Clinic exhibiting bacterial etiolation and/ or decline symptoms were sampled for the presence of bacterial pathogens. Isolated bacteria were identified using rRNA sequencing of the 16S subunit

$X$. translucens were only isolated in $26 \%$ of samples. Frequently isolated bacterial species were examined for pathogenicity to 4-week-old ' $\mathrm{G} 2$ ' $\mathrm{CBG}$ seedlings and 8-week-old 'A-1' CBG turfgrass stands in the greenhouse. While results confirmed pathogenicity of A. avenae and $X$. translucens, Pantoea ananatis was also shown to infect CBG turf; although pathogenicity varied among isolated strains. These results illustrate that multiple bacteria are associated with bacterial disease and shed new light on culturable bacteria living in CBG turfgrass putting greens. Future research to evaluate additional microorganisms (i.e., bacteria and fungi) could provide new information on host-microbe interactions and possibly develop ideas for management tactics to reduce turfgrass pests.
\end{abstract} and internal transcribed spacer region (16S-23S or ITS). Results showed diverse bacteria isolated from symptomatic turf and A. avenae and

Creeping bentgrass (CBG) (Agrostis stolonifera L.) is a popular cool season turfgrass species that is often intensely managed throughout much of the transition climate zone, a region of the United States in between the southern region, where warm season turfgrasses are acclimated, and the northern region, where cool season turfgrasses are acclimated (Dunn and Diesburg 2004). The transition zone is not particularly suitable to cool or warm season grasses species, yet both types grow well at different times of each year. Regardless, turfgrass managers are charged with the daunting task of maintaining aesthetics and superior playing quality in an environment with numerous abiotic and biotic stresses. Over the years, many fungal diseases have been described on CBG along with the successful deployment of management practices to reduce their severity. Yet, bacteria have rarely been problematic and are rarely considered important in turfgrass pathology. During the late 1970s, 'Toronto' (C-15) CBG suffered from numerous diseases resulting in a significant decline of the $\mathrm{C}-15$ cultivar, otherwise known as the C-15 problem (Vargas 1981). While fungal diseases were problematic on $\mathrm{C}-15$, this research presented the first report of bacterial disease in turfgrass systems and it was determined that Xanthomonas translucens (reported as Xanthomonas campestris pv. graminis) infection resulted in vascular wilt (Roberts et al. 1981). Bacterial wilt of CBG was described as stunting, wilting from the tip to the crown, and a blue-green color associated with affected plants. Reports of bacterial wilt on CBG decreased in later years as new varieties were developed and planted on golf course putting greens (Roberts 1981). Bacterial wilt (X. translucens pv. poae) became more problematic on annual bluegrass (Poa annua L. f. reptans (Hausskn) T. Koyama) resulting in similar symptoms in the eastern United States and Japan (Mitkowski et al. 2005).

${ }^{\dagger}$ Corresponding author: J. A. Roberts; E-mail: robertsj@umd.edu

C 2018 The American Phytopathological Society
Additional keywords: ecology, environmental microbiology.

In 2009, a severe decline of CBG was observed after the development of widespread chlorotic, abnormal elongation of turfgrass stems and leaves (i.e., etiolation) on golf course putting greens in North Carolina. While etiolation had been previously observed, the etiology of this condition remained unclear until recent reports (Giordano et al. 2010). Previous assumptions as to the cause included fungal infection, nutrient deficiencies, pesticide applications, and/or heat and drought stress. Giordano et al. (2010) demonstrated that Acidovorax avenae caused decline of $\mathrm{CBG}$ in controlled environmental conditions. Previously, Furuya et al. (2009) reported Acidovorax sp. as a cause of bacterial brown stripe on CBG in Japan. Reports of bacterial disease in turfgrass coupled with stressful environmental conditions observed in 2010 and 2011 incited fear among turfgrass managers resulting in numerous site visits and sample submissions to the NC State Turfgrass Disease Diagnostic Clinic. While numerous samples exhibited characteristic bacterial streaming, a diagnostic feature described by Giordano et al. (2010), isolation of A. avenae from CBG exhibiting etiolation and decline was not consistent. Xanthomonas translucens can cause bacterial etiolation on CBG and the ability of different bacteria to incite similar symptoms in CBG has caused many to question if other bacteria are involved (Roberts et al. 2014).

Due to the rarity of bacterial diseases in turfgrass systems, little is known regarding how bacteria, both beneficial and pathogenic, persist and survive in turfgrass ecosystems. Sundaram et al. (1988) previously isolated $\mathrm{N}_{2}$ fixing Azospirilla bacteria from Kentucky bluegrass (Poa pratensis L.) seeds and roots. Elliot et al. (2004) also showed that soil in the southeastern United States contained numerous culturable bacteria and actinomycetes that were stable over time and location and that CBG roots had different microbial populations compared with bermudagrass roots. Other studies have shown that microbial antagonists can reduce fungal diseases like summer patch (Magnaporthe poae Landschoot and Jackson) and brown patch (Rhizoctonia solani Kuhn) (Giesler and Yuen 1998; 
Kobayashi et al. 1995). While these and other studies present considerable information regarding the soil microflora and the efficacy of biological controls in turfgrass systems, research is needed to determine what bacteria are present in relation to etiolation and decline of CBG. Based on the sudden emergence of suspected bacterial disease, the objectives of this research were to (i) isolate and identify bacteria from turfgrass exhibiting symptoms of bacterial etiolation and/or decline and (ii) characterize frequently isolated bacteria for pathogenicity to CBG.

\section{MATERIALS AND METHODS}

Isolation of bacteria. From 2010 to 2014, bacteria isolates were obtained from CBG samples submitted to the NC State

TABLE 1. Identification of bacterial isolates from 2010 to 2014 using 16S rRNA sequencing homology compared with known sequences in the Basic Local Alignment Search Tool for nucleotides (BLASTn)

\begin{tabular}{|c|c|c|}
\hline Genus & $\begin{array}{l}\text { Predominant species isolated } \\
\text { within each genera }\end{array}$ & $\begin{array}{l}\text { Number of } \\
\text { isolates within } \\
\text { genus }\end{array}$ \\
\hline Acidovorax & avenae $(18)^{\mathrm{z}}$ & 18 \\
\hline Acinetobacter & $\begin{array}{l}\text { baumannii }(2), \text { calcoaceticus }(2), \text { and } \\
\text { oleivorans }(1)\end{array}$ & 5 \\
\hline Aeromonas & veronii & 1 \\
\hline Agrobacterium & vitis & 2 \\
\hline Agrococcus & jejuensis & 1 \\
\hline Arthrobacter & defluvii & 1 \\
\hline Bacillus & $\begin{array}{l}\text { aerophilus }(1), \text { cereus }(2), \\
\text { mycoides }(1), \text { pumilus }(2), \text { and } \\
\text { thuringiensis }(6)\end{array}$ & 12 \\
\hline Brevibacillus & agri & 1 \\
\hline Burkholderia & cepacia (2) and uncultured (1) & 3 \\
\hline Chryseobacterium & $\begin{array}{l}\text { hugamense }(1), \text { rigui }(2), \\
\text { taichungense }(1), \text { and } \\
\text { taiwanense }(4)\end{array}$ & 8 \\
\hline Cronobacter & dublinensis & 1 \\
\hline Curtobacterium & flaccumfaciens (2) and pusillum (1) & 3 \\
\hline Enterobacter & cloacae (11) and hermanii (1) & 13 \\
\hline Escherichia & coli (1) and hermannii (2) & 3 \\
\hline Exiguobacterium & acetylicum & 1 \\
\hline Flavobacterium & johnsoniae & 1 \\
\hline Herbaspirillum & huttiense (4) and seropedicae (1) & 5 \\
\hline Labrys & okinawensis & 1 \\
\hline Luteibacter & rhizovicinus (1) and yeojujensis (4) & 5 \\
\hline Mesorhizobium & ciceri & 1 \\
\hline Microbacterium & $\begin{array}{l}\text { binotii }(1), \text { oleivorans }(4), \\
\text { hydrocaronoxydans }(1), \\
\text { paradoxans }(2), \text { and testaceum }(9)\end{array}$ & 17 \\
\hline Niabella & yanshanensis & 1 \\
\hline Paenibacillus & hunanensis (5) and illinoisensis (1) & 6 \\
\hline Pantoea & $\begin{array}{l}\text { agglomerans (3), ananatis (18), and } \\
\text { eucrina (6) }\end{array}$ & 27 \\
\hline Pedobacter & heprinus (1) and saltans (1) & 2 \\
\hline Pseudomonas & $\begin{array}{l}\text { alcaligenes }(1), \text { cichorii }(11), \\
\text { fluorescens }(1), \text { fulva }(9), \\
\text { mendocina }(1), \text { montellii }(1), \\
\text { oryzihabitans }(1), \text { peli }(1), \\
\text { pseudoalcaligenes }(1), \text { putida }(2), \\
\text { stutzeri }(6), \text { and trautweineii }(1)\end{array}$ & 37 \\
\hline Rheinheimera & tangshanensis & 1 \\
\hline Rhizobium & $\begin{array}{c}\text { pseudoryzae (1) and } \\
\text { taibaishanense (1) }\end{array}$ & 3 \\
\hline Sphingobacterium & $\begin{array}{l}\text { multivorum (2), siyangensis }(2), \text { and } \\
\text { yabuuchiae }(1)\end{array}$ & 5 \\
\hline Sphingomonas & sanguinis (1) and yabuuchiae (1) & 2 \\
\hline Stenotrophomonas & $\begin{array}{l}\text { acidaminiphila }(1) \text { and } \\
\text { maltophilia }(24)\end{array}$ & 25 \\
\hline Variovorax & paradoxus & 2 \\
\hline Xanthomonas & translucens & 14 \\
\hline Total-33 & & 228 isolates \\
\hline
\end{tabular}

${ }^{\mathrm{z}}$ Numbers in parentheses designate to the number of individual species isolated within each genus.
Turfgrass Diagnostic Clinic exhibiting symptoms of etiolation and/ or unexplained (i.e., fungal pathogens not observed) chlorosis and decline. While environmental data were not collected from individual samples, the majority of samples submitted over the 4-year period were sent from golf courses experiencing environmental stress (i.e., extended daytime temperatures $>32^{\circ} \mathrm{C}$ and drought). To isolate bacteria, individual turfgrass plants were extracted from the turfgrass stand surface, root and senescent tissue were removed and discarded, and the remaining plant material was surface disinfested in diluted sodium hypochlorite solution $(0.6 \% \mathrm{NaOCl} ; 10 \%$ Clorox $)$ for $5 \mathrm{~min}$. The resulting tissue was then rinsed in sterile $\mathrm{dH}_{2} \mathrm{O}$, placed on a sterile glass slide in a drop of sterile $\mathrm{dH}_{2} \mathrm{O}$, and cut to allow bacteria to stream out into the sterile $\mathrm{H}_{2} \mathrm{O}$ for at least $2 \mathrm{~min}$. The slide was examined for bacterial streaming and the resulting bacterial suspension was transferred to three individual petri dishes containing nutrient agar (NA). After 24 to $48 \mathrm{~h}$, the 3 most prevalent individual colonies exhibiting distinct colony morphology were isolated using a transfer loop to T-streak each bacterium on a fresh NA plate (Harley 2004). Once bacteria were isolated, cultures were transferred to nutrient broth and allowed to grow for at least $48 \mathrm{~h}$ before being transferred to $20 \%$ glycerol and placed in cold storage at $-80^{\circ} \mathrm{C}$. Bacteria were regenerated from cold storage for experimental use by streaking a transfer loopful of frozen material on nutrient agar.

Identification of isolates. For identification, rRNA was extracted from bacterial samples by placing a 3 - to $5-\mu 1$ volume of bacteria cells scraped from growth on a NA plate in a $1.5-\mathrm{ml}$ capacity microcentrifuge tube containing $50 \mu \mathrm{l}$ of sterile $\mathrm{dH}_{2} \mathrm{O}$. The resulting suspension contained in each microcentrifuge tube was heated in boiling water for $10 \mathrm{~min}$ to extract bacteria rRNA. After boiling, $1 \mu$ l of the product was added to a polymerase chain reaction (PCR) of $15 \mu \mathrm{l}$ in volume that was prepared having concentrations of $1.5 \mathrm{mM} 10 \times$ PCR Buffer (Bioline USA, Taunton, MA), $0.8 \mathrm{mM}$ dNTP mix (Bioline), $0.2 \mu \mathrm{M}$ primer 63f (CAG GCC TAA CAC ATG CAA GTC), $0.2 \mu \mathrm{M}$ primer $1387 \mathrm{r}$ (GGG CGG WGT GTA CAA GGC), and $2.5 \mathrm{U}$ of Taq polymerase (Bioline) (Marchesi et al. 1998). The $16 \mathrm{~S}$ subunit amplification was performed using thermal cycling conditions consisting of an initial denaturation step at $94^{\circ} \mathrm{C}$ for $2 \mathrm{~min}$; followed by 30 cycles of $94^{\circ} \mathrm{C}$ for $30 \mathrm{~s}, 57^{\circ} \mathrm{C}$ for $30 \mathrm{~s}$, and $72^{\circ} \mathrm{C}$ for $45 \mathrm{~s}$; and a final extension step at $72^{\circ} \mathrm{C}$ for $5 \mathrm{~min}$. Positive PCR amplification was confirmed by gel electrophoresis before purifying samples using ExoSAP-IT (Affymetrix, Santa Clara, CA); $1.5 \mu$ l of ExoSAP-IT was added to $6 \mu$ of PCR product and subjected to thermal cycling conditions of $37^{\circ} \mathrm{C}$ for $30 \mathrm{~min}$ followed by $80^{\circ} \mathrm{C}$ for $20 \mathrm{~min}$. Purified samples were sequenced using BigDye v3.0 obtained from the Duke Center for Genomic and Computational Biology. Sample reactions ( $10 \mu \mathrm{l}$ in volume) were prepared and sequencing reactions were performed using thermal cycling conditions of an initial denaturation step at $96^{\circ} \mathrm{C}$ for $2 \mathrm{~min}$, followed by 40 cycles of $96^{\circ} \mathrm{C}$ for $30 \mathrm{~s}, 50^{\circ} \mathrm{C}$ for $15 \mathrm{~s}$, and $60^{\circ} \mathrm{C}$ for $4 \mathrm{~min}$. The resulting reaction volume was submitted to the Duke University Genome Sequencing Laboratory for sequencing. Sequencing results for each sample submission were assembled into a consensus 16S rRNA sequence using both forward and reverse reactions with CLC Genomics Workbench (CLC-GW) v7.5 (CLC bio: A QIAGEN Company, Boston, MA). Preliminary identification was obtained using the Basic Local Alignment Search Tool (BLASTn) utility in the National Center for Biotechnology Information (NCBI) Database (https://www.ncbi.nlm.nih.gov/). Reference sequences of identified bacteria genera and species were obtained using the NCBI Reference Sequence database and all 16S sequences were aligned using the native analysis (settings: slow and accurate) in CLC-GW. Phylogenetic analysis of aligned sequences was performed by a neighbor-joining tree construction using the Jukes-Cantor nucleotide distance measure with a 10,000 bootstrap replicate analysis (Jukes and Cantor 1969). The resulting tree was converted to an unrooted, color-coded by genera, circular cladogram using the Interactive Tree of Life (Letunic and Bork 2011). 
Bacteria genera that were isolated in high frequency and previously determined pathogenic to CBG were also identified using rRNA sequencing of the $16 \mathrm{~S}-23 \mathrm{~S}$ or internal transcribed spacer (ITS) region using the primers 1493f (AGT CGT AAC AAG GTA GCC GT) and 23r (GTG CCA AGG CAT CCA CC) (Schaad 2001; Schaad et al. (2008)). Purification and sequencing reactions were performed using the techniques described above. Reference sequences cited in previous literature of multiple species from each genera were obtained from the NCBI Reference Sequence database and all sequences were aligned in CLC-GW along with phylogenetic analysis using the Jukes-Cantor nucleotide distance measure and 10,000 bootstrap replicates.

Pathogenicity testing. With the exception of Stenotrophomonas spp., only frequently isolated bacteria (i.e., $>10$ isolations) were examined for pathogenicity to CBG seedlings using a modified method developed by Roberts (1981). A 'G-2' CBG seed was planted in seed starter trays filled with calcined clay (Turface Allsport; Profile Products LLC, Buffalo Grove, IL) and allowed to grow in a greenhouse at $\sim 30^{\circ} \mathrm{C}$ daytime and $\sim 20^{\circ} \mathrm{C}$ nighttime that received irrigation two times daily. Seedlings were fertilized every 7 days by applying 1/2 strength Hoagland's solution (Hoagland and Arnon 1950) plus iron and algaecide (VWR) at a rate calibrated to deliver $4.9 \mathrm{~kg} \mathrm{~N} \mathrm{ha}^{-1}$. For each treatment, a bacterial suspension was prepared by flooding fully colonized NA plates with $100 \mathrm{mM}$ phosphate $+1 \%$ peptone buffer $(\mathrm{pH}=7.0)$ and scraping cells loose with a sterile inoculating loop. The resulting suspension was then diluted to $10^{9}$ colony forming units (CFUs) per milliliter. Plants were inoculated after 4 weeks growth (i.e., three to five leaf stage) by removing each plant from the soil, trimming the leaf tissue to $2 \mathrm{~cm}$, and submerging each of the four plants (to serve as replicates) into the bacterial suspension of each treatment (A. avenae, Enterobacter cloacae, Pantoea ananatis, Microbacterium testacium, Pseudomonas putida, Pseudomonas fulva, X. translucens, and a noninoculated control) for $5 \mathrm{~min}$ on a shaker bench at $100 \mathrm{rpm}$. Sterile phosphate buffer plus peptone was used for the noninoculated control. After inoculation, each of the four individual plants were replanted in $3.8 \times 21 \mathrm{~cm}$ cone-tainers (Ray Leach Conetainers, Stuewe and Sons Inc., Tangent, OR) filled with calcined clay and placed back on the greenhouse bench. Plant quality was rated on a scale of 1 to $9(1=$ completely dead and $9=$ healthy $)$ every other day for signs of chlorosis and decline. All data were subjected to analysis of variance using the MIXED procedure in SAS 9.4 and means were separated using Tukey's honest significant difference.

Seedling inoculations that resulted in significant decline were examined in further detail by inoculating multiple plants grown in cone-tainers to form small turf stands similar to a putting green. CBG 'A-1' was seeded in cone-tainers $(3.75 \times 20 \mathrm{~cm})$ filled with a sterilized mixture of sand and peat ( $85 \%$ sand $/ 15 \%$ peat). The CBG was allowed to grow on a greenhouse bench at $\sim 28^{\circ} \mathrm{C}$ daytime and $\sim 20^{\circ} \mathrm{C}$ nighttime for 8 weeks receiving irrigation two times daily and fertilization with $1 / 2$ strength Hoagland's solution applications calibrated to deliver $4.9 \mathrm{~kg} \mathrm{~N} \mathrm{ha}^{-1}$ every 7 days. Turf was cut at $\sim 1 \mathrm{~cm}$ to maintain a dense turf canopy similar to a putting green surface. Bacterial suspensions (A. avenae-1, A. avenae-2, P. ananatis-1, P. ananatis-2, P. ananatis-3, P. ananatis-4, P. ananatis-5, E. cloacae, and $E$. hermanii, and nontreated control) were prepared as previously discussed to obtain bacterial suspensions containing $10^{9} \mathrm{CFUs} \mathrm{ml}^{-1}$. Acidovorax isolates were included as positive controls. Inoculation was performed by cutting the turf surface similar to normal trimming with scissors dipped in bacterial cell suspensions of each isolate. Scissors were dipped after each cutting and all replicates were trimmed with inoculated scissors prior to flame sterilization to move to successive isolates. The remaining cell suspension for each isolate was applied to the turf surface as a drench using an atomizer bottle. After inoculation, plants were randomized within a cone-tainer rack with a 1-cone-tainer buffer between blocks. The rack was placed in a sealed clear plastic bin (Cambro Co., Huntington Beach, CA) for $48 \mathrm{~h}$ to maintain high humidity and then transferred to the greenhouse bench for observation. Plants were inoculated using the same method twice 7 days apart (30 May and 6 June) and symptoms of etiolation were rated when observed by counting abnormally long and chlorotic leaves within each replicate. Turf quality was rated every few days using a scale of 1 to $9(1=$ completely dead and $9=$ healthy $)$ and turf density and color were all components of turf quality. Data were subjected to analysis of variance using the MIXED procedure in SAS 9.4 (SAS Institute Inc., Raleigh, NC) and means were separated using Tukey's honest significant difference.

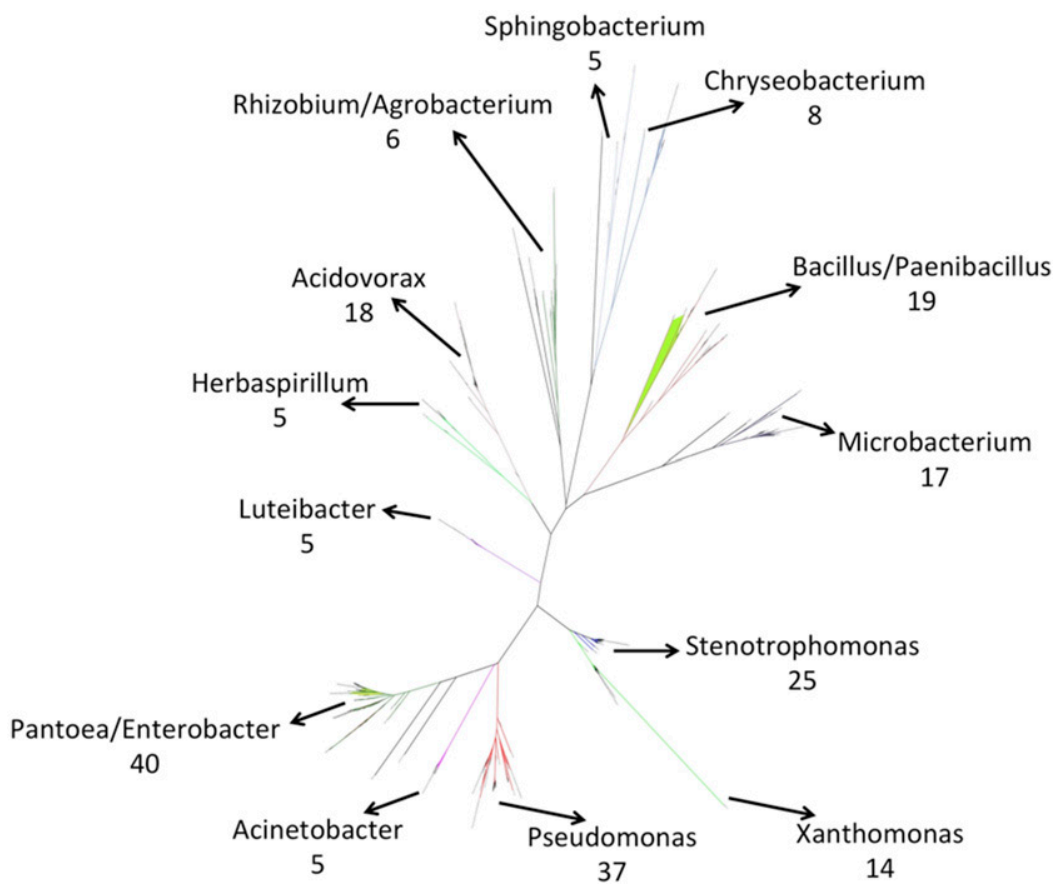

Fig. 1. Phylogenetic relationships of bacteria associated with bacterial etiolation and/or decline isolated from 2010 to 2014. Alignment was performed using rRNA sequences of the 16S subunit in CLC-Genomics Workbench7.5 and the unrooted tree was generated using the Jukes-Cantor method and 10,000 bootstrap replicates in CLC-GW and the Interactive Tree of Life (iTOL) online tool. 


\section{RESULTS}

Isolation and identification of bacteria associated with turfgrass bacterial disease. A total of 228 isolates were collected from 78 samples submitted from 62 locations over a 4-year period. Samples were obtained from Arkansas, California, Georgia, Illinois, Kentucky, Missouri, New Jersey, North Carolina, Ohio, Pennsylvania, Tennessee, Virginia, and West Virginia. Results from BLASTn alignments of individual isolates identified 33 different genera encompassed by various species within each genus (Table 1). When comparing 16S rRNA sequences from isolates obtained in our study in the BLASTn, 211 isolates exhibited 98 to $100 \%$ similarity to known sequences, 13 isolates were 95 to $97 \%$ similar, 3 isolates were 90 to $94 \%$ similar, and 4 isolates had $<90 \%$ similarity. Instances of lower percent homology to a specific match were supported with sequence data from ITS sequences to positively identify each bacterial isolate (data not shown). Phylogenetic analysis of the $16 \mathrm{~S}$ rRNA sequence data proved similar to the BLASTn results, which formed 13 distinct clusters encompassed within the Actinobacteria, Bacteriodetes, Firmicutes, $\alpha$-Proteobacteria, $\beta$-Proteobacteria, and $\gamma$-Proteobacteria (Fig. 1). Of all bacteria isolated, $\gamma$-Proteobacteria exhibited the greatest diversity with six different clusters as observed in the phylogenetic tree. Closely related genera were not easily differentiated within the $16 \mathrm{~S}$ rRNA phylogenetic tree, such as genera within the family Enterobacteriaceae, as Pantoea and Enterobacter species grouped together instead of in defined groups.
Sequencing of the ITS rRNA region was also performed for 18 Acidovorax isolates and 12 Xanthomonas isolates (Figs. 2 and 3). These sequences were often more variable across genera and sometimes difficult to amplify when compared with the $16 \mathrm{~S}$ subunit. Multiple sequence copies of variable length were occasionally present in a few amplifications, which resulted in lower quality sequence data in these samples. The vast majority of our isolates collected from turfgrass grouped well with known strains of A. avenae. Acidovorax 10895-A and Acidovorax 11415-C2 were more similar to A. citrulli and $A$. facilis than $A$. avenae subsp. avenae (Fig. 2). Comparing ITS sequences in $X$. translucens isolates to known reference sequences also showed multiple relationships across these bacteria. Of the 12 isolates sequenced, seven showed strong similarity to $X$. translucens pv. poae; one isolate was similar to $X$. translucens pv. graminis while the additional four isolates were grouped outside of the known grass pathovars with translucens and undulosa (Fig. 3).

Characterization of pathogenicity of bacteria frequently associated with bacterial disease in CBG. Seedling inoculations were performed to obtain a quick and reliable method to select bacteria for additional screening on turfgrass stands. Replicated inoculations were similar across experiments and are presented together in Figure 4. A. avenae, P. ananatis, and X. translucens substantially reduced seedling quality 10 days after inoculation, whereas E. cloacae, M. testaceum, P. putida, and P. fulva inoculations did not affect seedling quality (Fig. 4). Following the seedling inoculations, $P$. ananatis was reisolated from symptomatic tissue, thus fulfilling

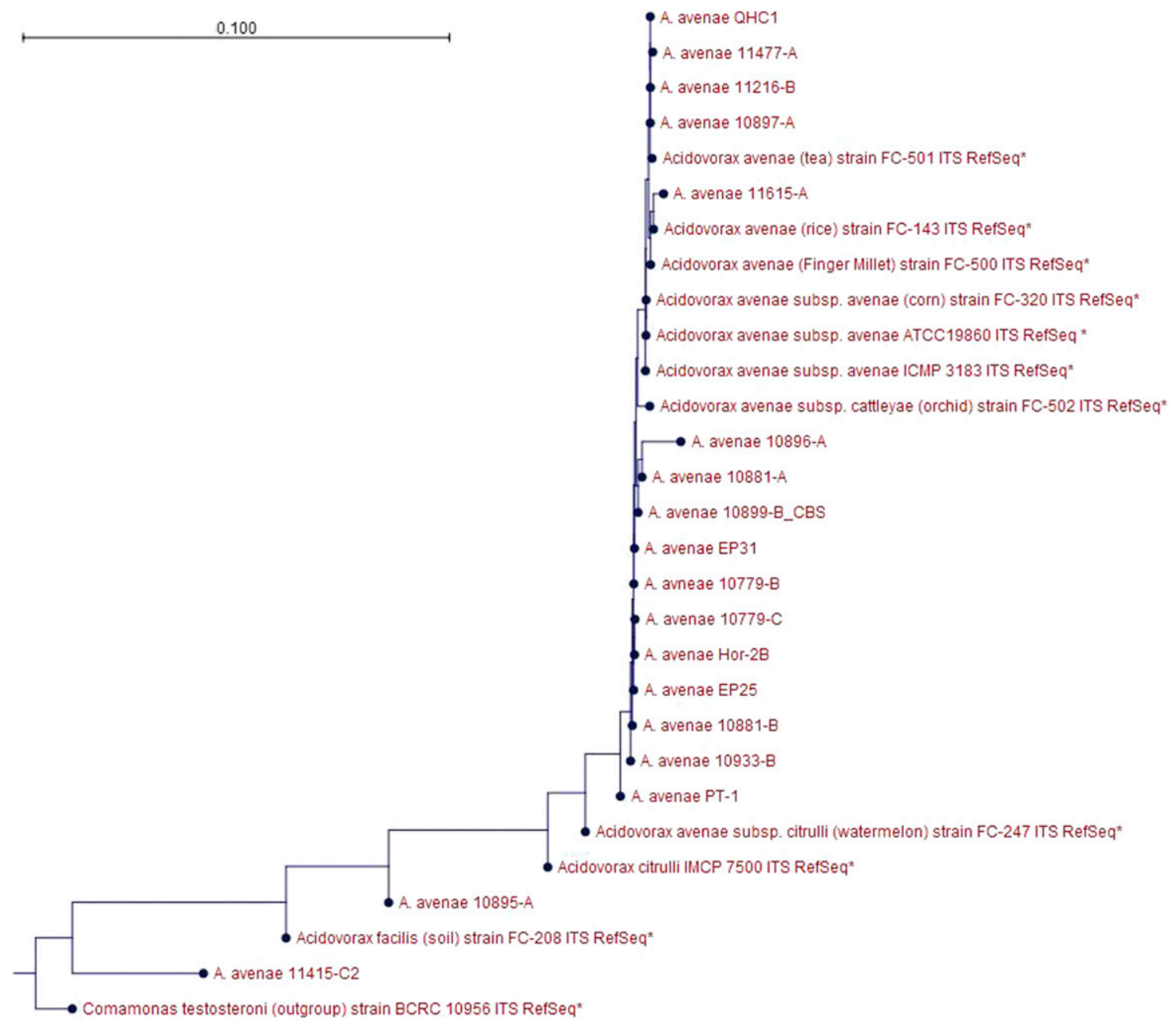

Fig. 2. Phylogenetic relationships of Acidovorax avenae bacteria associated with bacterial etiolation and/or decline isolated from 2010 to 2014 . Alignment was performed using rRNA sequences of the 16S-23S (ITS) subunit in CLC-Genomics Workbench7.5 and the tree was generated using the Jukes-Cantor method and 10,000 bootstrap replicates in CLC-GW. Sequences designated as RefSeq* were obtained from the NCBI database on the basis of Schaad et al. (2008) and Comamonas testosterone strain BCRC 10956 was used as an outgroup in the analysis. 


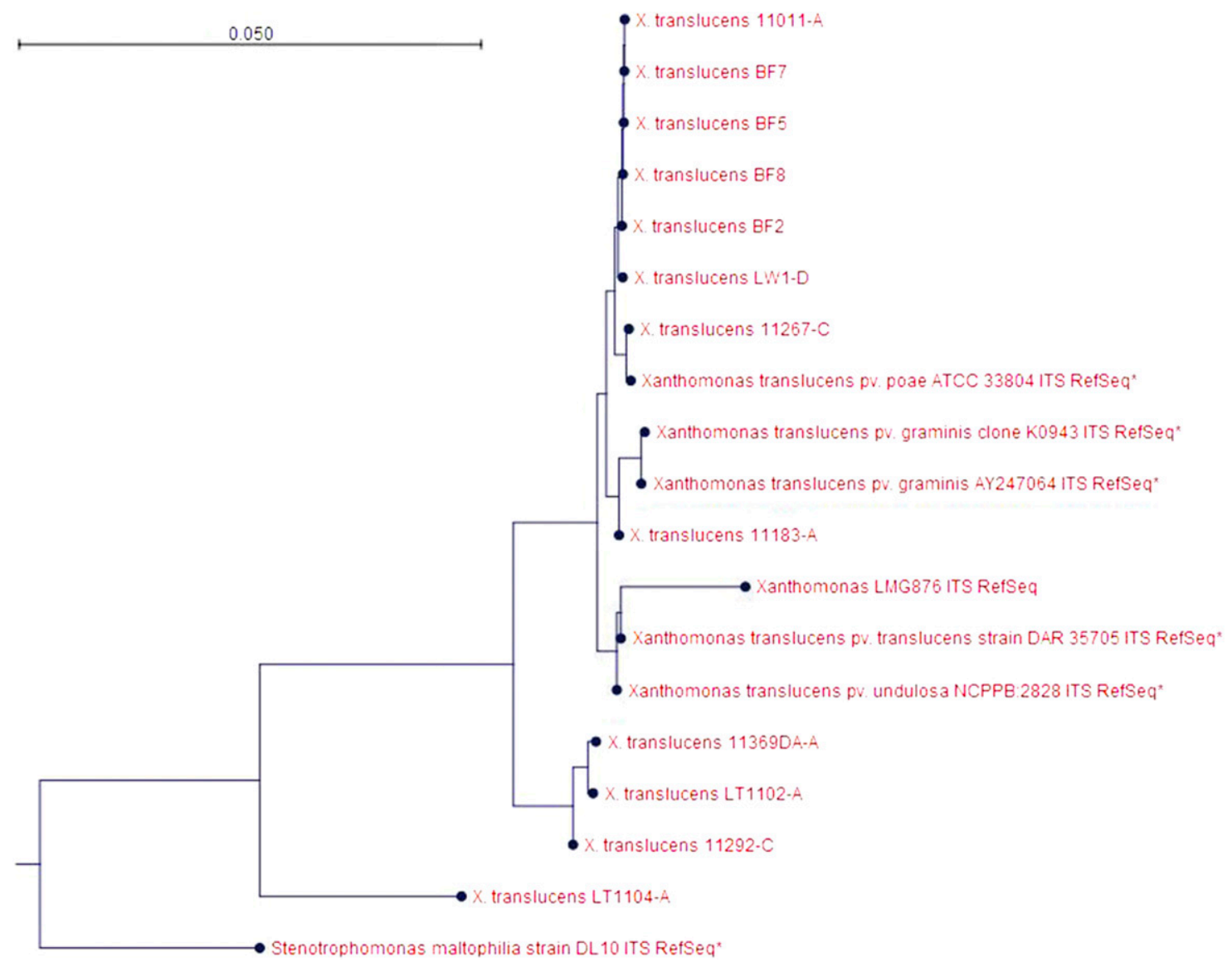

Fig. 3. Phylogenetic relationships of Xanthomonas translucens bacteria associated with bacterial etiolation and/or decline isolated from 2010 to 2014 . Alignment was performed using rRNA sequences of the 16S-23S (ITS) subunit in CLC-Genomics Workbench7.5 and the tree was generated using the Jukes-Cantor method and 10,000 bootstrap replicates in CLC-GW. Sequences designated as RefSeq* were obtained from the NCBI database on the basis of Chaves and Mitkowski (2013) and Stenotrophomonas maltophilia strain DL10 was used as an outgroup in the analysis.

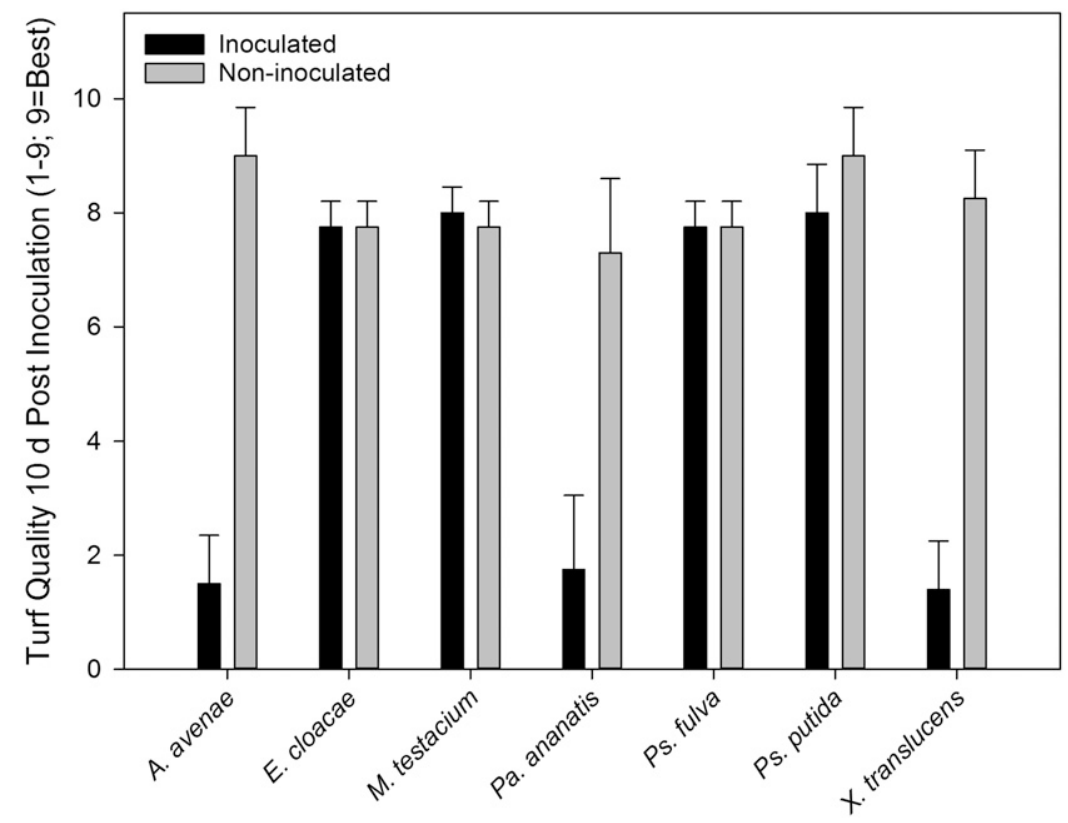

Fig. 4. Impact of bacteria on turf quality of 'G-2' creeping bentgrass seedlings. Quality was rated on a scale of 1 to $9(1=$ completely dead and $9=$ completely healthy) and results are presented as inoculated versus noninoculated, which were combined from multiple experiments. Error bars represent Tukey's honest significant difference at the 0.05 probability level. 
Koch's postulates. Further examination of $P$. ananatis isolates on more established turfgrass resulted in quality reductions that varied across the experiments. Inoculation of positive controls (A. avenae-1 and -2) did result in etiolation symptoms 6 days postinoculation, whereas all P. ananatis strains did not (Fig. 5). In the same experiment, turf quality was reduced by $P$. ananatis -5 and -6 and $A$. avenae -1 at 6 days after the initial inoculation (Table 2). All other species and isolates tested did not reduce turf quality compared with the noninoculated control (Table 2). Six days following the second inoculation, isolates of A. avenae -1 and -2 , and $P$. ananatis $-1,-5$, and -6 all reduced turf quality. At the same time, turf quality of plants inoculated with E. cloacae, P. ananatis-2, -3 , and -4 were not different from the noninoculated control. Reductions in turf quality were observed as chlorosis, dieback from the leaf tip, and thinning.

\section{DISCUSSION}

It should be noted that results from our research only included culturable bacteria. Bacteria exist in many different ecosystems and many species are considered nonculturable using traditional techniques (Pham and Kim 2012). Future research incorporating newer metagenomic approaches, such as sequencing of environmental DNA, will yield more information regarding the presence of bacteria and additional microorganisms associated with turfgrass disease. Regardless, this research improves our knowledge of the bacteria isolated in conjunction with etiolation and decline of CBG. Examination of submitted turf samples over a 4-year period showed that $A$. avenae and $X$. translucens were not frequently isolated from declining turfgrass. Previous reports indicate that $A$. avenae was the sole cause of etiolation and decline and yet our work does not demonstrate constant association with these symptoms in the field. Sequencing of $16 \mathrm{~S}$ rRNA can provide identification to genus in most cases and of the 78 samples submitted to the NC State Turf Diagnostic Clinic exhibiting symptoms of bacterial etiolation and/or decline, Acidovorax was isolated from 10 locations and Xanthomonas was isolated from 12 locations; samples from two locations contained both A. avenae and $X$. translucens. In reality, only $26 \%$ of the samples submitted suspecting bacterial decline and etiolation yielded either A. avenae or X. translucens. Although research from Giordano et al. (2012), Roberts et al. (2015a, b), and this work demonstrate decline and/or etiolation in pathogenicity assays, it remains unclear why

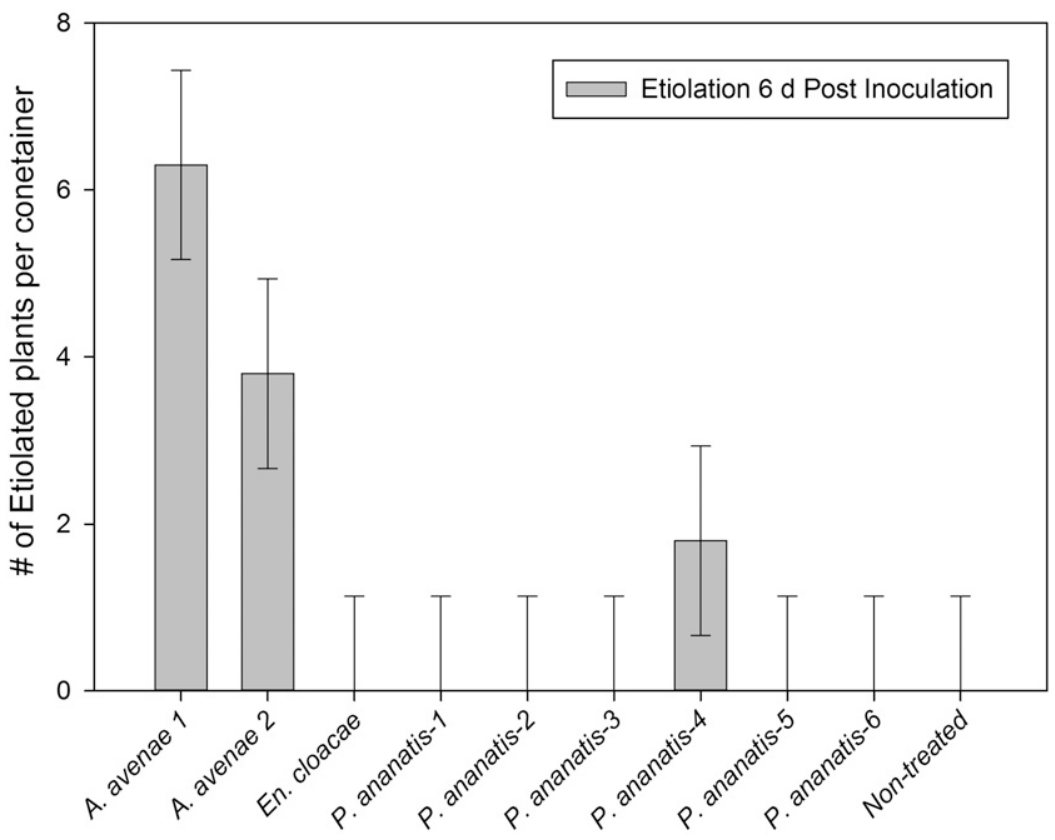

Fig. 5. Etiolation of 'A-1' creeping bentgrass 6 days postinoculation with bacteria. Number of etiolated plants represent averages over four cone-tainer replicates and error bars represent Tukey's honest significant difference at the 0.05 probability level.

TABLE 2. Turf quality of 'A-1' creeping bentgrass after inoculation with bacteria species associated with bacterial etiolation

\begin{tabular}{|c|c|c|c|c|c|c|c|c|c|}
\hline \multirow[b]{3}{*}{ Bacteria } & \multicolumn{9}{|c|}{ Turf quality ${ }^{z}$} \\
\hline & \multicolumn{9}{|c|}{ ( 1 to $9 ; 9=$ best) } \\
\hline & 30 May & 1 Jun & 2 Jun & 3 Jun & 5 Jun & 9 Jun & 12 Jun & 16 Jun & 23 Jun \\
\hline A. avenae 2 & 7.0 & 6.8 & 6.5 & 6.5 & $5.3 \mathrm{abcd}$ & $5.5 \mathrm{ab}$ & $4.1 \mathrm{~cd}$ & $5.0 \mathrm{ab}$ & 4.8 \\
\hline Enterobacter cloacae & 6.8 & 6.5 & 6.8 & 6.8 & $5.5 \mathrm{abcd}$ & $6.8 \mathrm{a}$ & $6.0 \mathrm{abc}$ & $5.1 \mathrm{ab}$ & 4.8 \\
\hline Pantoea ananatis 1 & 7.0 & 7.0 & 7.0 & 6.8 & $6.5 \mathrm{ab}$ & $4.8 \mathrm{ab}$ & $4.0 \mathrm{~cd}$ & $3.5 \mathrm{ab}$ & 4.3 \\
\hline P. ananatis 2 & 7.0 & 6.8 & 6.8 & 6.5 & $5.5 \mathrm{abcd}$ & $5.8 \mathrm{ab}$ & $5.5 \mathrm{abc}$ & $4.8 \mathrm{ab}$ & 5.0 \\
\hline P. ananatis 5 & 6.5 & 6.3 & 6.5 & 6.0 & $4.3 \mathrm{~d}$ & $4.5 \mathrm{ab}$ & $4.1 \mathrm{~cd}$ & $3.8 \mathrm{ab}$ & 4.3 \\
\hline P. ananatis 6 & 6.3 & 5.8 & 5.8 & 5.0 & $4.3 \mathrm{~d}$ & $5.8 \mathrm{ab}$ & $4.5 \mathrm{bcd}$ & $4.3 \mathrm{ab}$ & 4.3 \\
\hline Nontreated & 7.0 & 7.0 & 7.3 & 7.0 & $7.0 \mathrm{a}$ & $7.0 \mathrm{a}$ & $6.9 \mathrm{a}$ & $5.4 \mathrm{a}$ & 5.5 \\
\hline Tukey's HSD & 1.2 & 1.7 & 2.0 & 2.2 & 2.0 & 2.8 & 2.1 & 2.5 & 2.6 \\
\hline \multicolumn{10}{|l|}{ Source of variation } \\
\hline Isolate & NS $₫$ & NS & NS & $*$ & $* * *$ & $* *$ & $* * *$ & $*$ & NS \\
\hline
\end{tabular}

${ }_{\mathrm{z}}$ Turf quality was rated on a scale of 1 to $9\left(1=\right.$ completely dead and $9=$ completely healthy) periodically after inoculation with bacteria $\left(10^{9} \mathrm{CFU} \mathrm{ml}^{-1}\right)$ on 30 May and 6 June 2014 . *, Significant at the 0.05 probability level; **, significant at the 0.01 probability level; ***, significant at the 0.001 probability level; and NS, not significant. 
etiolation/decline is frequently observed. Moving forward, turfgrass managers finding one of the bacteria listed above should be cautious in drastically changing management practices nor should the absence of confirming the presence of these organisms exclude the possibility of bacterial infection and colonization.

Isolated bacteria associated with turfgrass samples were diverse belonging to four distinct phyla (Actinobacteria, Bacteriodetes, Firmicutes, and Proteobacteria), 7 classes, 11 orders, 22 families, and 33 genera. A high percentage of isolates exhibited strong similarity $(>95 \%)$ to known isolates using BLASTn. Yarza et al. (2008) state that 16S rRNA gene sequences hold a reasonable threshold value of $95 \%$ homology for similar genera while Janda and Abbott (2007) state that 99\% sequence similarity is required for species identification. When comparing isolates in a phylogenetic analysis, we did observe some resolution problems with sequences believed to be in the Enterobacter, Escherichia, and Pantoea genera; however, Janda and Abbott (2007) previously mention that groups within the Enterobacteriaceae can have resolution difficulties when using $16 \mathrm{~S}$ rRNA to identify genera and species. Stenotrophomonas and Xanthomonas isolates also clustered close together but this was expected with the similarities among these bacteria sequences. Based on these results, additional sequencing is necessary to confirm species identification within these genera.

While multiple copies of ITS can exist between similar strains of the same species, use of this sequence can be used to provide better resolution at the species and subspecies level (Barry et al. 1991). Similar results were observed with ITS rRNA sequences of Acidovorax and Xanthomonas isolates examined in our study. Acidovorax isolates obtained in our study showed strong similarity with multiple known Acidovorax isolates that were previously used in reclassification of subspecies of A. avenae (cattleyae, citrulli, and oryzae) into A. cattleyae, A. citrulli, and A. oryzae (Schaad et al. 2008). Giordano et al. $(2010,2012)$ previously reported $A$. avenae subsp. avenae as the cause of bacterial etiolation and decline on CBG on the basis of percent similarity to reference 16S rRNA sequences; however, the analysis of 16S and ITS sequences obtained in our study do not provide a clear resolution of subspecies within the Acidovorax genus. Based on research presented here and previous work utilizing $16 \mathrm{~S}$ sequencing, it should be noted that the specific species and subspecies of Acidovorax pathogens occurring in turfgrass systems is currently unresolved. Previous reports were able to differentiate these bacteria on the basis of DNA/DNA reassociation testing (Schaad et al. 2008; Willems et al. 1992), which may be useful in the future if more specific primers are not developed.

The use of ITS sequencing for resolving $X$. translucens pathovars also showed variability among isolates. These results were not surprising as previous literature by Chaves and Mitkowski (2013) showed that ITS can be used to differentiate both graminis and poae pathovars of $X$. translucens. While isolates in our study were taken from CBG, it appears that both $X$. translucens pv. poae and $X$. translucens pv. graminis can be isolated from CBG turf. Moreover, additional isolates of $X$. translucens showed greater similarity to pathovars translucens and undulosa meaning that additional work is needed to resolve Xanthomonas species occurring in CBG turf. Previous research on Xanthomonas in turfgrass has been limited to phytopathogens (Chaves and Mitkowski 2013; Giordano et al. 2015; Mitkowski et al. 2005; Roberts et al. 2014). Strong variability is known to exist within the xanthomonads and Vauterin et al. (2000) state that additional opportunistic Xanthomonas spp. may exist with many different plants therefore also contributing to population heterogeneity. Future work that includes additional strains and sequence data using species-specific primers, such as DNA gyrase $\mathrm{B}(\mathrm{gyr} B)$, may provide better resolution to species and subspecies or pathovar designations in both Acidovorax and Xanthomonas bacteria occurring in turfgrass systems (Dauga 2002).

Characterization of pathogenicity with selected isolates from frequently isolated bacteria was quickly differentiated using the seedling technique previously developed by Roberts (1981). Seedling inoculations support recent reports of $A$. avenae and $X$. translucens pathogenicity on CBG (Furuya et al. 2009; Giordano et al. 2012, 2010; Roberts 1981; Roberts et al. 1981). Although not presented here, additional greenhouse experiments performed at the same time of this research also illustrated the ability of $X$. translucens to cause bacterial etiolation on CBG turf (Roberts et al. 2014). Further inoculations with $P$. ananatis showed variable results across different strains. While $A$. avenae isolates within our greenhouse inoculation served as a positive control, only $50 \%$ P. ananatis isolates reduced turf quality compared with noninoculated CBG across multiple experiments. None of the P. ananatis isolates caused etiolation as only chlorosis and tip dieback occurred after inoculation. Etiolation was also uncommon on turf samples with $P$. ananatis as chlorosis and thinning were more often problematic in submitted field samples infected with that bacterium alone. Reports of plant pathogenic $P$. ananatis have become more frequent in recent years with infections occurring on maize (Zea mays L.) (Alippi and López 2010), onion (Allium cepa L.) (Kim et al. 2012), and rice (Oryza sativa L.) (Lee et al. 2010). From agricultural crops to forest tree species, $P$. ananatis is a ubiquitous epiphyte that is regarded as an emerging pathogen and can colonize diverse environments worldwide (Coutinho and Venter 2009). In our research, the frequency of $P$. ananatis isolations were more frequent than $A$. avenae and $X$. translucens combined. To our knowledge, this is the first report of $P$. ananatis as a pathogen of turfgrass, although inoculation results showed differences in virulence among strains isolated. Future research to include field inoculations is needed to better understand the impact of various $P$. ananatis strains on $\mathrm{CBG}$ as results from recent field inoculations with $A$. avenae have varied from greenhouse studies. Inoculations performed by Giordano et al. (2012) resulted in necrosis of multiple CBG cultivars in the greenhouse whereas field inoculations by Roberts et al. (2015a, b) caused etiolation symptoms without decline.

In summary, our research shows that multiple bacteria are capable of infecting CBG turfgrass putting greens; however, the degree and severity of symptoms varies with the each of the bacteria tested. Moving forward, turfgrass managers should avoid equating etiolation and decline solely with $A$. avenae. While research surrounding management of etiolation and decline has offered some solace to turfgrass managers, current recommendations are not conclusive. Additional research to continue screening bacterial species may demonstrate that even more bacteria are capable of infecting turfgrass species. Identification and characterization of all bacteria associated with bacterial etiolation and decline will ultimately improve our understanding of the etiology of this phenomenon and may result in improved management techniques for control. Moreover, this research sheds new light on the presence of bacteria in turfgrass putting greens. Future research to understand how microbes survive and interact with plant hosts in turfgrass systems in a community structure may provide new means for beneficial bacteria that support plant growth or serve as biological controls for a variety of diseases.

\section{ACKNOWLEDGMENTS}

We thank A. Putman, R. Garris, M. Davis, K. Charon, and J. Doherty for their aid in sample collection and genetic analysis. We also recognize the maintenance staff at the Method Road Greenhouse Facility and Phytotron at NC State University for their aid in turfgrass maintenance. Creeping bentgrass seed for this research was provided by Tee-2-Green. Funding for this research was provided by the United States Golf Association and Syngenta Crop Protection.

\section{LITERATURE CITED}

Alippi, A. M., and López, A. C. 2010. First report of leaf spot disease of maize caused by Pantoea ananatis in Argentina. Plant Dis. 94:487.

Barry, T., Colleran, G., Glennon, M., Dunican, L. K., and Gannon, F. 1991. The $16 \mathrm{~S} / 23 \mathrm{~S}$ ribosomal spacer region as a target for DNA probes to identify eubacteria. Genome Res. 1:51-56. 
Chaves, A., and Mitkowski, N. 2013. Virulence of Xanthomonas translucens pv. poae isolated from Poa annua. Plant Pathol. J. 29:93-98.

Coutinho, T. A., and Venter, S. N. 2009. Pantoea ananatis: An unconventional plant pathogen. Mol. Plant 10:325-335.

Dauga, C. 2002. Evolution of the gyrB gene and the molecular phylogeny of Enterobacteriaceae: A model molecule for molecular systematic studies. Int. J. Syst. Evol. Microbiol. 52:531-547.

Dunn, J., and Diesburg, K. 2004. Turf Management in the Transition Zone. John Wiley \& Sons, New York.

Elliott, M. L., Guertal, E. A., and Skipper, H. D. 2004. Rhizosphere bacterial population flux in golf course putting greens in the southeastern United States. Hortic. Sci. 39:1754-1758.

Furuya, N., Ito, T., and Tsuchiya, K. 2009. Occurrence of bacterial brown stripe of creeping bentgrass on golf course green in Kyushu. J. Fac. Agric. Kyushu Univ. 54:4.

Giesler, L. J., and Yuen, G. Y. 1998. Evaluation of Stenotrophomonas maltophilia strain $\mathrm{C} 3$ for biocontrol of brown patch disease. Crop Prot. 17: 509-513.

Giordano, P. R., Zeng, Q., Dykema, N. M., Detweiler, A. R., and Vargas, J. M., Jr. 2015. First report of Xanthomonas translucens causing wilt disease on perennial ryegrass (Lolium perenne) in the United States. Plant Dis. 99: 1270.

Giordano, P. R., Chaves, A. M., Mitkowski, N. A., and Vargas, J. M. 2012. Identification, characterization, and distribution of Acidovorax avenae subsp. avenae associated with creeping bentgrass etiolation and decline. Plant Dis. 96:1736-1742.

Giordano, P. R., Vargas, J. M., Detweiler, A. R., Dykema, N. M., and Yan, L. 2010. First report of a bacterial disease on creeping bentgrass (Agrostis stolonifera) caused by Acidovorax spp. in the United States. Plant Dis. 94: 922.

Harley, J. P. 2004. Laboratory Exercises in Microbiology. McGraw-Hill Science/ Engineering/Math

Hoagland, D. R., and Arnon, D. I. 1950. The water-culture method for growing plants without soil. California Agricultural Experiment Station Circular 347. The College of Agriculture, University of California, Berkeley.

Janda, J. M., and Abbott, S. L. 2007. 16S rRNA gene sequencing for bacterial identification in the diagnostic laboratory: Pluses, perils, and pitfalls. J. Clin. Microbiol. 45:2761-2764.

Jukes, T. H., and Cantor, C. R. 1969. Evolution of Protein Molecules. Academic Press, New York.

Kim, J., Choi, O., and Kim, T. S. 2012. An outbreak of onion center rot caused by Pantoea ananatis in Korea. Plant Dis. 96:1576.

Kobayashi, D. Y., Guglielmoni, M., and Clarke, B. B. 1995. Isolation of the chitinolytic bacteria Xanthomonas maltophilia and Serratia marcescens as biological control agents for summer patch disease of turfgrass. Soil Biol. Biochem. 27:1479-1487.

Lee, H. B., Hong, J. P., and Kim, S. B. 2010. First report of leaf blight caused by Pantoea agglomerans on rice in Korea. Plant Dis. 94:1372.
Letunic, I., and Bork, P. 2011. Interactive Tree Of Life v2: Online annotation and display of phylogenetic trees made easy. Nucleic Acids Res. 39:W475-W478.

Marchesi, J. R., Sato, T., Weightman, A. J., Martin, T. A., Fry, J. C., Hiom, S. J., and Wade, W. G. 1998. Design and evaluation of useful bacteriumspecific PCR primers that amplify genes coding for bacterial 16S rRNA. Appl. Environ. Microbiol. 64:795-799.

Mitkowski, N. A., Browning, M., Basu, C., Jordan, K., and Jackson, N. 2005. Pathogenicity of Xanthomonas translucens from annual bluegrass on golf course putting greens. Plant Dis. 89:469-473.

Pham, V. H., and Kim, J. 2012. Cultivation of unculturable soil bacteria. Trends Biotechnol. 30:475-484.

Roberts, D. L. 1981. Page 115 in: Bacterial Wilt of Toronto Creeping Bentgrass. Department of Botany and Plant Pathology, Michigan State University, East Lansing, MI.

Roberts, D. L., Vargas, J. M., Baker, K. K., and Hooper, G. R. 1981. Association of a bacterium with a disease of toronto creeping bentgrass. Plant Dis. 65:1014-1016.

Roberts, J., Tredway, L., and Ritchie, D. F. 2014. First report of Xanthomonas translucens causing etiolation on creeping bentgrass turf in IL, KY, and NC. Plant Dis. 98:839.

Roberts, J. A., Kerns, J. P., and Ritchie, D. F. 2015a. Bacterial etiolation of creeping bentgrass as influenced by biostimulants and trinexapac-ethyl. Crop Prot. 72:119-126.

Roberts, J. A., Ritchie, D. F., and Kerns, J. P. 2015b. Plant growth regulator effects on bacterial etiolation of creeping bentgrass putting green turf caused by Acidovorax avenae. Plant Dis. 100:577-582.

Schaad, N. W. 2001. Laboratory Guide for Identification of Plant Pathogenic Bacteria, 3rd ed. American Phytopathological Society, St. Paul, MN.

Schaad, N.W., Postnikova, E., Sechler, A., Claflin, L.E., Vidaver, A.K., Jones, J.B., Agarkova, I., Ignatov, A., Dickstein, E., and Ramundo, B. A. 2008. Reclassification of subspecies of Acidovorax avenae as A. avenae (Manns 1905) emend., A. cattleyae (Pavarino 1911) comb. nov., A. citrulli Schaad et al. 1978. comb. nov., and proposal of A. oryzae sp. nov. Syst. Appl. Microbiol. 31:434-446.

Sundaram, S., Arunakumari, A., and Klucas, R. V. 1988. Characterization of Azospirilla isolated from seeds and roots of turf grass. Can. J. Microbiol. 34:212-217.

Vargas, J. M. 1981. Management of Turfgrass Diseases. Burgess Publishing Co., Minneapolis, MN.

Vauterin, L., Rademaker, J., and Swings, J. 2000. Synopsis on the taxonomy of the genus Xanthomonas. Phytopathology 90:677-682.

Willems, A., Goor, M., Thielemans, S., Gillis, M., Kersters, K., and Ley, J. D. 1992. Transfer of several phytopathogenic Pseudomonas species to Acidovorax as Acidovorax avenae subsp. avenae subsp. nov., comb. nov., Acidovorax avenae subsp. citrulli, Acidovorax avenae subsp. cattleyae, and Acidovorax konjaci. Int. J. Syst. Bacteriol. 42:107-119.

Yarza, P., Richter, M., Peplies, J., Euzeby, J., Amann, R., Schleifer, K.-H., Ludwig, W., Glöckner, F. O., and Rosselló-Móra, R. 2008. The All-Species Living Tree project: A 16S rRNA-based phylogenetic tree of all sequenced type strains. Syst. Appl. Microbiol. 31:241-250. 